\title{
Analysis on the Development Trend of Chinese local fast fashion brands under the influence of the epidemic
}

\author{
XuRan Sun ${ }^{1, a}$, Hongzhong Shan ${ }^{1, b}$ \\ ${ }^{1}$ School of business, Beijing Institute Of Fashion Technology, Beijing, China
}

\begin{abstract}
New impact of the coVID-19 outbreak, the key layout of offline store numerous fast fashion brands suffered huge losses, and electronic business channels rely on local web celebrity the advantage of fast fashion brand also highlights, along with the rise of the tide, the main consumer groups are becoming more and more young and consumption trend of change, China local fast fashion brands must reasonable analysis of its future development trend, to usher in the vast space to grow up.
\end{abstract}

\section{THE INTRODUCTION}

The outbreak has led to huge changes in the global fast fashion industry. Since the outbreak of the epidemic, all kinds of phenomena indicate that fast fashion brands are in urgent need of changing their economic model to seek new development. As the Chinese market the popularity of the Internet and the emergence of new retail clothing products supply faster and faster, with a fast fashion brand whether can continue with Chinese consumer loyalty and mid-range fashion crowd, how Chinese fast fashion brand development, event is not only the survival of fast fashion brand, is China's most people fashion way how to continue on the event.

\section{DEVELOPMENT STATUS OF FAST FASHION BRANDS UNDER THE INFLUENCE OF THE EPIDEMIC}

\subsection{Fast fashion concept and main features}

Fast fashion is a clothing production mode that "responds quickly to the fashion and consumption demand of customers". It aims to optimize the supply chain, shorten the cycle from production to sales of clothing products, and provide customers with fashionable clothing at a low price. The main features of fast fashion are as follows:

Rapid design: Behind the rapid development of fast fashion lies a strong team of buyers and designers, who are responsible for walking through fashion shows or shopping malls to gather information about current market demand. Teams of designers are responsible for designing the next season's fashions based on forecasts, and some brands collaborate with big names to keep their products cheap and promote fashion and originality.
Quick Purchase: Fast Fashion For the seasonal clothing, has developed from the traditional four seasons to seven or even eight seasons, the production cycle is shortened. This requires that the time from fabric supply to the manufacturer should be shortened as much as possible. As the production of fast fashion brands mostly adopts the OEM mode, brands should combine the specific situation of the OEM when purchasing fabrics.

Rapid manufacturing: In order to save costs, fast fashion brands mainly choose OEM mode for production in Asia, Europe and other developing countries. In order to quickly respond to the market, fast fashion brands will also set up production bases in sales regions.

Fast logistics: Fast fashion brands require that the output time from design to shelf should be shortened as much as possible, which puts forward high requirements on logistics, warehousing and transportation. For example, ZARA adopts self-built logistics, and all market supplies come from warehouses in Spain, while H\&M adopts third-party logistics.

\subsection{Big fast fashion brands suffered huge losses in the first half year}

Affected by the epidemic, all the major fast fashion brands are facing severe challenges. Topshop, H\&M, GAP and others announced to close a number of stores around the world, in order to mitigate the losses caused by the epidemic, in order to overcome the crisis of survival.

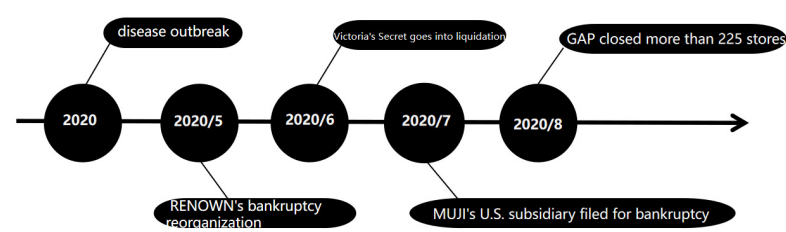

Figure 1. Enterprises applying for bankruptcy liquidation during the epidemic 
RENOWN, a Japanese clothing giant, began bankruptcy restructuring on May 15th. Founded in 1902, RENOWN, which includes more than 30 international brands such as ArnoldPalmer and Hiroko Oshino, RENOWN fell into financial difficulties after it made large investments during the bubble economy.

On June 9, 2020, the British company of Victoria's Secret, a famous lingerie brand based in New York, went into liquidation, putting more than 800 jobs at risk due to mismanagement and an epidemic.

On July 10, 2020, Ryokan, parent company of Japanese retail giant Muji, plans to announce that its US subsidiary has filed for bankruptcy with debts of $\$ 64$ million (6.7 billion yen) due to the coVID-19 outbreak, which has forced all stores in the US to suspend operations since March 17, and the ongoing loss of Muji's US business.

On Aug 27, 2020, The GAP Group announced that it expects to close more than 225 GAP stores this year as it reports its second-quarter fiscal 2020 results.

\subsection{The development speed of fast fashion industry is slowing down}

In recent years, with the continuous change of people's consumption demand, the appeal of fast fashion brands is gradually declining, and it is difficult to sustain the excessively fast store experience. However, with the development of resource-intensive and labor-intensive industries facing difficulties, fast fashion brands' profit space has been gradually compressed and the development speed has slowed down significantly due to the inflexible response of the management team. The chart below shows the growth of new stores of fast fashion brands in mainland China from 2016 to 2019.

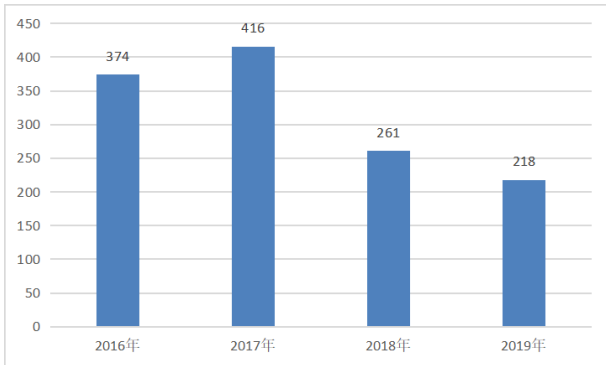

Figure 2. Example of a figure caption. Growth of new stores of fast fashion brands in mainland China from 2016 to 2019

TABLE 1. GROWTH RATE OF NEW STORES OF FAST FASHION BRANDS IN MAINLAND CHINA FROM 2017 TO 2019

\begin{tabular}{|l|l|l|l|}
\hline Year & $\mathbf{2 0 1 7}$ & $\mathbf{2 0 1 8}$ & $\mathbf{2 0 1 9}$ \\
\hline $\begin{array}{l}\text { Rate of } \\
\text { increase }\end{array}$ & $11 \%$ & $-37 \%$ & $-16 \%$ \\
\hline
\end{tabular}

From the chart analysis, it can be seen that the number of new fast fashion stores in China has been declining in the past two years. In addition to the positive growth rate of $11 \%$ for fast fashion brand stores in The mainland in 2017, the growth rate is negative in $2018-37 \%$ and 2019 $16 \%$. According to incomplete statistics, in 2019, eight fast fashion brands, including H\&M, ZARA, Uniqlo, MJstyle, Muji, UR, C\&A and GAP, added a total of 218 stores (excluding upgraded and re-installed stores) in the mainland, hitting a record low.

\subsection{Fast fashion brands in China are developing rapidly}

At present, the growth rate of domestic economy and household income is gradually slowing down, and consumers are beginning to get rid of the blind worship of high-end brands and high unit prices. As the fast fashion craze fades away, the growth of fast fashion brands diverges. Against the background of consumers returning to rational consumption, Uniqlo has successfully complied with consumers' pursuit of high cost performance.

In April 2019, Internet Weekly and eNet Research Institute jointly released the 2019 Fast fashion Brand Ranking list. Uniqlo, ZARA and Hando ranked in the top three of the 150 FMCG fashion brands, followed by H\&M, Adidas, Nike, ONLY, VERO MODA, Semir and Taiping bird.

In comparison to the top five of the 2018 list, Adidas dropped from second to fifth, Han Du Clothing moved into the top three, ZARA jumped from third to second, and Uniqlo and H\&M remained unchanged.

TABLE 2. TOP FAST FASHION BRANDS 2019

\begin{tabular}{|l|l|l|l|l|l|}
\hline Ranking & Brand & IPower & IBrand & ISite & $\begin{array}{l}\text { Total } \\
\text { score }\end{array}$ \\
\hline 1 & UNIQLO & 98.90 & 94.18 & 90.45 & 97.11 \\
\hline 2 & ZARA & 98.75 & 92.96 & 90.18 & 96.73 \\
\hline 3 & $\begin{array}{l}\text { Handu } \\
\text { Group }\end{array}$ & 97.32 & 94.73 & 92.47 & 96.32 \\
\hline 4 & H\&M & 97.21 & 92.08 & 89.54 & 95.42 \\
\hline 5 & Adidas & 97.37 & 91.14 & 88.04 & 95.17 \\
\hline 6 & Nike & 96.20 & 90.37 & 86.00 & 94.02 \\
\hline 7 & ONLY & 94.70 & 87.52 & 89.93 & 92.79 \\
\hline 8 & $\begin{array}{l}\text { VERO } \\
\text { MODA }\end{array}$ & 92.39 & 96.60 & 86.10 & 92.61 \\
\hline 9 & Semir & 91.81 & 95.96 & 87.05 & 92.17 \\
\hline 10 & waxwing & 92.59 & 93.06 & 85.75 & 92.00 \\
\hline
\end{tabular}

Source: Internet Weekly

It can be seen from the list that although after a round of shuffling, the domestic brands that can be listed are still the original traditional clothing brands or taobao-based brands such as Handu Clothing. Local fast fashion brands such as UR, MJstyle and Hot Air are still far behind H\&M and Zara.

Korea all the clothes can one third, such as tao brand and improve China's apparel industry electricity permeability and online shopping increasingly developed, especially live as new traffic track, gave rise to the eu emilia, lino kiki, etc with the owner, the anchor head by $\mathrm{C} 2 \mathrm{M}$ mode, to develop their own products, transform the upstream supply chain, thus preempted the fast fashion industry a certain market share. 


\section{ANALYSIS OF FACTORS CONTRIBUTING TO THE RISE OF CHINESE LOCAL FAST FASHION BRANDS}

While foreign fast fashion brands are exiting the Chinese market at a faster pace, Chinese local fast fashion brands are gradually favored by more and more consumers. With the upgrading of Chinese consumption, the market influence of local brands is gradually released. In addition to the mature and huge local supply chain, local fast fashion brands and web celebrity brands have also been rising with the help of online channels in recent years, which are mainly manifested in the following aspects.

\subsection{Local brands focus on "Chinese design", and IP co-branded with Chinese elements}

Domestic popular logo continues to rise and gradually occupies a certain market share in the fast fashion market. In 2018, Tmall national fashion action took taiping bird, li ning, CLOT, JNBY, AngelChen and so on to the New York fashion week. The development of "national fashion" attracted increasing attention in the industry. Many domestic brands began to pay attention to "Chinese design" and integrate Chinese cultural genes into the expression context of international youth through IP joint cooperation and other ways. According to the 2020 China Consumer Brand Development Report by Aliresearch, the market share of online Chinese brands reached $72 \%$ in 2019. In FMCG, Over the past two years, Chinese brands have captured the market share of foreign brands in more than $4 / 5$ segments.

\subsection{Local brands' online share keeps increasing, squeezing foreign brands' market share}

In terms of marketing methods, with the rise of ecommerce live streaming, $\mathrm{C} 2 \mathrm{M}$ and $\mathrm{MCN}$ concepts, young people, as the main force of fast fashion consumption, are more willing to accept new things, such as live streaming and goods delivery on Taobao and Douyin, and the leading layout of local fast fashion enterprises online will also promote the structural optimization of sales channels in the industry. For example, anta, Li Ning, Xtep and other sports brands attract consumers' attention by releasing copywriting videos of fitness movements, live training sessions, online sports challenges, and attaching online links to purchase fitness equipment.

The change of consumers' preferences in fast fashion industry is also an important reason for the rise of domestic brands. With the continuous improvement of the consumption power and influence of The Chinese market and the enhancement of the cultural confidence of young Chinese groups, the young groups developed with the Internet are no longer blindly pursuing foreign brands, but are willing to support high-quality domestic products, which makes the competitiveness of domestic fast fashion brands continuously improved.

\subsection{Local brands appear in New York Fashion Week to attract industry attention}

"National fashion" has become a new highlight of 2020 Fashion week. Li Ning and Taiping Bird have participated in international fashion week for many times, including more and more Chinese designer brands appearing in fashion week, and local brand Semir also appeared in Milan Fashion Week in 2019.

The appearance of li Ning, a veteran fashion brand, in the fashion week makes people see the determination of the old fashion brand to change the image of the trend. The fame and flow come together. Anta, Jiangnan Cloth clothing, Bosideng and other brands have also been exposed in the international fashion week through different channels. But that does not mean that every brand that makes it to fashion week can be as "successful" as Li Ning. Gymnastics prince Li Ning himself is the brand story, wearing Li Ning people, also can feel the spirit of sports inherited; Or Supreme. In a major cultural country, the name "national tide" cannot be used without convincing connotation. With an increasing number of Chinese brands appearing at fashion weeks in recent years, Li Ning and Taiping Bird staged a stunning turnaround in 2019 as The "National trend" went global.

\section{DeVelopment TRend of Local Fast FASHION BRANDS IN CHINA}

\subsection{Brands attract consumers through IP joint brands and web celebrity flash stores punching in}

Local fast fashion brands hold on to young consumer groups by launching collaborations with designer brands or other brands. Within a day of their launch, the six units had sold more than 10,000 units in their Tmall stores. Peppa Pig \& Anta co-branded series, Pacific Bird \& Iron Arm Co-branded Artoki; Pony Polly vintage series \&Only; The metropolitan Museum of Art and Eveley co-branded garments became popular quickly, and these co-branded garments were well received by consumers and greatly enhanced the brand's reputation. Some brands can launch IP joint pop-up stores to attract web celebrity clock, quickly increase consumer traffic.

Cooperate with famous designers, animation IP, film and TV to launch joint funds to achieve cross-industry cooperation, to meet the young generation's pursuit of cultural feelings and personality. Cooperative elements such as animation IP and street culture artists also attract a large number of male consumers to stabilize the consumer group and avoid brand aging. This crossover seems full of adventure, but completely accords with the consumption trend of contemporary young people do STH unconventional or unorthodox, clothing label is authorized to IP to the root cause of the apparel industry bring huge benefits, on the way to enhance the competitiveness of the brand, is critical to find the right IP license, a good IP license, can quickly open the market, increase sales, even achieve brand concept upgrade. 


\subsection{Brand joint KOL anchors carry goods for digital transformation}

During the epidemic, offline physical stores could not operate normally, but Taiping Bird's e-commerce channel advantages are prominent, and online retail sales grew rapidly. During the reporting period, the online operating revenue reached 1.124 billion yuan, up $25.64 \%$ compared with the same period of last year. While traditional ecommerce businesses continue to make efforts, taiping actively embraces new social retail channels such as applet and web celebrity live broadcast. Retail partners in stores participate in segment marketing, store live broadcast, and applet retail, etc., rapidly improving retail performance. Nearly 100,000 fans watched the first store broadcast on the fourth day of the lunar New Year online. During Tmall's "618" period, its brands successively visited the direct broadcasting rooms of wei ya and li jiaqi, as well as those of stars such as liu tao, Lin yun, Lin yilun and liuyan, and accumulated sales volume of more than 100,000 pieces.

In essence, the experience upgrading in the Internet era is to create a digital consumption trend, while fast fashion brands, which are good at "quick reverse" mode, are more sensitive to the digital transformation. In the past year, all the major fast fashion brands have more or less laid out their plans for digital transformation, with online sales blossoming and live streaming becoming the biggest assist.

\subsection{The brand should make proper use of fashion week to gain publicity}

The "Going to sea" show is only the first step for clothing brands to enter the international market. Supporting the "national trend" is a win-win situation for both brands and merchants. However, fashion Week is not as sacred as imagined.

The experience of wearing clothes is dominated by the public aesthetic, so the brand needs to take into account the public cultural aesthetic. Combined with the popular concept of the continuation of local culture, the real national trend can lead the domestic fashion, rather than blindly imitating each other or completely absorbing the foreign trend. People's recognition of the national trend is also an important factor affecting the further expansion of these local brands.

\subsection{Fast fashion brands timely adjust their business model}

In mid-March, Spanish fast-fashion giant Inditex, Zara's parent company, announced the closure of more than half of its stores around the world, saying that "the coVID-19 outbreak has had an extremely significant impact on the group's business". Swedish fast-fashion giant H\&M also said overall sales fell 46 percent in March as it closed nearly 70 percent of its stores worldwide during the outbreak. Uniqlo, the Japanese fast-fashion giant, also said it expected sales to fall $8.8 \%$ for the year as a whole.
During the epidemic, consumer purchasing power fell sharply, and with it textile consumption. Especially for brands or enterprises that have many offline stores but do not pay attention to the development of online channels, high cost and low income will bring them a double blow. Therefore, for fast fashion brands, it is very necessary to timely change the business model. Fast fashion brands should deal with inventory flexibly and combine shortterm demand with long-term demand in production. At the same time, they should pay attention to the expenditure of fixed costs such as staff salary, store rent and order cost.

\section{CONCLUSION}

The impact of the epidemic is both an opportunity and a challenge for fast fashion clothing brands. In the new retail era, it has become a new development model to carry goods via Internet live streaming and IP joint carrying. Local fast fashion brands in China should timely adjust their operation mode, keep up with the pace of The Times, and more accurately find consumers' demands and brand positioning, so as to realize the quality upgrade of clothing products and meet consumers' demands.

\section{SUPPORTED BY:}

The project in the fund of 20801 capacity building of science and technology innovation servicee of Beijing Institute of Fashion Technology (KJCX20801-30299/003)

\section{REFERENCE}

1. A Brief Discussion on the cost management of "fast fashion" brands -- Taking ZARA of Spain as an example [J]. China Business Review,2020(18):24-25.

2. Wang Jiajia, Gu Zhaohui, ZHANG Xiyang, He Pei. Analysis on the relationship between the pose of models in the window of fast fashion brands and consumer psychology $[\mathrm{J}]$. Shandong textile science and technology,2020,61(04):37-41.

3. Anna, Zhang Jianlei, Cheng Longdi. The influence of fast fashion brand image on buying intention [J]. Journal of textiles,2020,41(08):108-114.

4. With the continuous collapse of global fast fashion, is there an opportunity for domestic brands? [J]. Chinese Journal of Glasses Science and Technology,2020(08):51.

5. Cao Zhuxin, Zhang Lei. Construction of flexible supply chain of fast fashion brand ZARA and its enlightenment $[\mathrm{J}]$. Modern business and trade industry, 2020,41(21):47-48.

6. Chu xiaojie. Research on fast fashion clothing brand communication based on WeChat platform [D]. Donghua University,2020.

7. Shuping. Brand New [J]. Shanghai Quality, 2020(06):27-30. 
8. Tian Yanhong. Discounts, store closures, plummeting performance... Fast fashion brand "fast" not up? [J]. Global Business Classics,2020(05):102107.

9. Zhiya. How fast fashion brands respond to the global epidemic [N]. China Apparel News,2020-04-10(011).

10. Zhang Meiyan, Liu Yubing. Suggestions on marketing promotion of "Fast Fashion" clothing brands in China [J]. Marketing,2020(09):16-17.

11. Wang Qiurong. Symbiosis with Sustainability -- A Discussion on the Crisis and Turning Point of fast Fashion industry [J]. Economic Guide to Sustainable Development,2019(08):44-48.

12. Bai Yanhui, Wang Hongfu. An analysis of joint marketing strategies of clothing brands $[\mathrm{J}]$. Chinese journal of clothing industry,2019,4(04):366-371.

13. Liu Huilin, Wang Xiaoshuai, Xu Di. Research on the functions and services of apparel retail terminals under the new retail model $[\mathrm{J}]$. Logistics technology,2019,42(08):53-56. 